\title{
The magical transformation contest in the ancient storytelling tradition
}

\author{
Ioannis M. KonstANTAKOS \\ National and Kapodistrian University of Athens \\ iokonstan@phil.uoa.gr
}

Recibido: 05-06-2015

Aceptado: 11-12-2015

\section{RESUMEN}

El concurso de transformación mágica, esquema narrativo difundido en la tradición popular, se presenta en dos variantes principales: los hechiceros que compiten pueden metamorfosearse en varios seres o crear esos seres por medios mágicos. En cualquier caso el concursante ganador da a luz criaturas más fuertes que superan las de su oponente. La segunda variante fue preferida en el antiguo Cercano Oriente (Sumeria, Egipto, Israel). La primera se puede encontrar en algunos mitos griegos sobre cambiadores de forma (por ejemplo, Zeus y Némesis). El mismo esquema narrativo puede haber influido en un episodio de la Novela de Alejandro (1.36-38), en el que Darío envía regalos simbólicos a Alejandro y los dos monarcas enemigos ofrecen contrastantes explicaciones de ellos. Esta historia griega racionaliza el concurso de cuento de hadas, transfiriendo las fantásticas hazañas de creaciones milagrosas a un plano secundario pero realista de metáfora lingüística.

Palabras clave: concurso mágico, transformación mágica, cuentos populares, Alejandro el Grande

\begin{abstract}
The magical transformation contest, a story-pattern widespread in folk tradition, occurs in two main variations: the competing sorcerers may metamorphose themselves into various beings or create these beings by magical means. In either case, the winning contestant brings forth stronger creatures which surpass those of his opponent. The second variant was favoured in the ancient Near East (Sumer, Egypt, Israel); the first one is traceable in Greek myths of shape-shifters (e.g. Zeus and Nemesis). The story-pattern may have influenced an episode of the Alexander Romance (1.36-38), in which Darius sends symbolic gifts to Alexander and the two enemy monarchs offer contrasting explanations of them. This Greek story rationalizes the fairytale contest, transferring the fantastic feats of miraculous creations to a secondary but realistic level of linguistic metaphor.
\end{abstract}

Keywords: contest in magic, magical transformation, folktales, Alexander the Great

\section{ANCIENT TALES OF MAGICAL TRANSFORMATION CONTEST}

The so-called "magical transformation contest" (or "transformation combat") is a story-pattern widespread in international popular tradition and frequently occurs in 
magical tales recorded in modern times around the world ${ }^{1}$. The roots of this storypattern can be shown to stretch back to antiquity, indeed to an exceedingly remote period (the late 3rd millennium B.C.); this makes the transformation contest one of the earliest attested folktales of humankind. No full examination of the ancient history of this narrative construct has been hitherto attempted. The first part of the present essay aspires to fulfil exactly this goal: namely, to collect and comparatively analyze all the known ancient examples of the magical transformation combat, whether they are contained in Near-Eastern or in Greek texts.

The typical storyline of the pattern involves two personages who are endowed with magical or supernatural capacities and compete with each other in ever stronger magical metamorphoses. One of the two protagonists begins by assuming the shape of a certain creature; then his adversary tries to outdo him by taking the form of a more powerful being, which chases the first magician's incarnation and threatens to kill it with its greater force. The competition and the pursuit continue until one of the opponents succeeds in eliminating the other by choosing the most suitable transformation into a superior creature. The forms taken by the two rivals are usually animals, but other entities (plants, natural elements, or even inanimate objects) may also be included in the sequence. For example, one of the adversaries turns himself into a small bird (e.g. a pigeon, swallow, or parrot); the other one becomes an eagle or hawk and hunts him. Subsequently, the first contestant is transformed into a fish, and his opponent into a seagull or a great pike. Finally, the former competitor may become a number of grains scattered on the ground; his enemy then takes the shape of a rooster and begins to eat the grains. But suddenly one of those grains turns into a fox and strangles the rooster, thus winning the victory. Other pairs of metamorphoses, attested in various popular traditions, consist in a hare and a greyhound or wolf, a fire and a water-carrier that quenches it, a lion and a cutting sword, a scorpion and a large serpent, a snake and a stone that crushes it etc.

In European and other modern folk traditions, the pattern is most commonly included in a particular tale-type (no. 325 in the standard inventory of Aarne, Thompson, and Uther), which brings an older and experienced magician into confrontation with his young and cunning pupil. However, the same pattern can also be accommodated in various other narratives, which may illustrate a contest between different kinds of magically endowed characters: for example, a witch and her servant boy, two queens with expertise in sorcery, a seer and a dragon, a ghoul and an old sage, a good and an evil spirit, a Jew and a clever seamstress, a malicious genie and a wise princess, a warrior and a griffin, an untamed princess and her suitor etc. ${ }^{2}$.

${ }^{1}$ For the typological classification of this folk narrative unit, see Thompson (1955-1958), motif D 615 ("Transformation combat", and its subdivisions D 615.1-5); cf. also ibidem, motifs D 642 ("Transformation to escape difficult situation"), D 642.2 ("Transformation to escape death"), D 651 ("Transformation to defeat enemies"), and D 1719.1 ("Contest in magic"). See also tale-type ATU 325 ("The magician and his pupil") in Uther (2004: I, 207-208).

${ }^{2}$ On the international dissemination of this folktale pattern, see Chauvin (1892-1922: V, 74-75, 198 200; VI, 110; VIII, 148-149); Köhler (1898: 138-139, 388, 556-558, 588); Bolte - Polívka (1913-1932: II, 60-69, 205-206); Cosquin (1922: 501-612); Penzer - Tawney (1924-1928: III, 194-195, 203-205; VIII, 79-80); Frobenius (1938: 14, 16-17); Kerényi (1939: 161-162); Schwarzbaum (1968: 5, 442); Thompson 
In most of the popular examples recorded in the modern age, the two adversaries metamorphose themselves into the various creatures. There is, however, a notable variation of the pattern, which occurs in a few divergent specimens; in these latter cases, the conflicting heroes do not change their own shape but produce other, independent animals or objects by means of wizardry. These magical creations, of course, follow the same pattern of climactic progress: the creature produced by the second contestant is stronger than that of the first one, and so forth, until one of the two combatants wins the final victory. For example, in a Dutch fairy story (narrated in a 16th-century chapbook), the master magician and his pupil compete while sitting at table. The master magically produces some rabbits; his disciple then creates a pair of hounds which spring on the rabbits and rip them apart. The teacher proceeds to bring forth a pool of water, to wash his hands in; but the pupil immediately turns the fresh water into black mud ${ }^{3}$.

In the Finnish epic Kalevala, which is based on folk songs collected by Elias Lönnrot, a similar competition occurs between the wrathful Master of Northland and the adventurous hero Lemminkäinen. The latter comes uninvited to the Northlander's feast hall, causes trouble, and provokes his angry host to a quarrel. The Master creates a pool of water by magic song; but Lemminkäinen produces by the same method a great bull which drinks the pool dry. Then the Northlander brings forth a wolf to slay the bull; Lemminkäinen makes a hare appear, which distracts the wolf's attention by hopping around him. The Master creates a dog with a hooked jaw to slaughter the hare; Lemminkäinen, however, conjures up a squirrel on a beam high on the roof, and the dog puts all his strength to bark at that little creature. The Master proceeds to magically fabricate a gold-breasted marten, which grabs the squirrel; but Lemminkäinen immediately produces a brown fox which eats the marten. The Northlander then brings forth a hen to strut in front of the fox's mouth; and Lemminkäinen counters him with a sharp-clawed hawk which seizes the hen. At that point the magical competition stops, and the two adversaries decide to fight each other in a real duel with swords. In this battle Lemminkäinen finally slays the Master of Northland ${ }^{4}$.

It is this second variation (with the opponents who produce competing creatures, rather than being themselves transformed into them) which is widely attested in the ancient world; it is recorded already from a very remote age and diffused over a large area of the Near East. The earliest known specimen is contained in a Sumerian epic poem, conventionally titled by modern scholars Enmerkar and Ensuhgirana from the names of the two royal adversaries in the story ${ }^{5}$. The poem is preserved on cuneiform tablets from the early 2 nd millennium B.C., but its composition is generally held to go

(1977: 69-70); Ford (1977: 159-164); Scherf (1995: I, 110-113, 748-751; II, 868-871, 1096-1098, 14361441); Clouston (2002: 210-224, 255-257); Marzolph - van Leeuwen (2004: 142, 338-339); Uther (2004: I, 207-208); de Blécourt (2013). Most of these works provide plenty of examples from various popular traditions around the world, as well as further bibliography.

${ }^{3}$ See Bolte - Polívka (1913-1932: II, 68).

${ }^{4}$ Kalevala, runo 27: "Magic and Mayhem". See Bosley (1999: 380-391).

${ }^{5}$ It is also known as Enmerkar and Ensuhkešdanna, according to an alternative mode of transcription of the second name. For text, translation, and analysis of the poem, see Berlin (1979); Vanstiphout (2003: 23-48); Black - Cunningham - Robson - Zólyomi (2004: 3-11). See also Kramer - Jacobsen (1954); 
back to the 21st century B.C., the period of the Third Dynasty of Ur and "golden age" of Sumerian literary activity. The legendary material per se may have been derived from even earlier times ${ }^{6}$.

In this work, the contest of magic is inscribed within a broader context of conflict between two enemy states: Unug (the Sumerian name of Uruk), the glorious city of Southern Mesopotamia, which is ruled by King Enmerkar; and Aratta, a legendary and fabulously rich town far to the east of Sumer, imagined to be situated somewhere on the Iranian plateaus. Ensuhgirana, the lord of Aratta, wishes to dominate over Unug and sends a provocative message to Enmerkar, demanding his submission. The Sumerian king naturally refuses and gives an angry and proud answer. Ensuhgirana cannot admit his defeat and resorts to the services of Urğirnuna, a skilful sorcerer from the town of Hamazu, who promises to make Unug surrender by his magical craft. The sorcerer indeed travels to Sumer and casts a spell on the cows and goats, which cease from making milk. Thus, great famine and desolation befall the Sumerian land. Then two brothers, a cowherd and a shepherd, pray to the sun-god for salvation. In response, a wise witch, called Sağburu, comes to confront Urğirnuna in a contest of wizardry at the bank of the Euphrates. The competition of Sağburu and Urğirnuna consists precisely in the magical fabrication of various animals. Each one of the adversaries throws a certain object of witcheraft ${ }^{7}$ into the river and draws out a magically produced creature (or group of creatures). Every time, however, Sağburu's creations are bigger, stronger, and wilder than those of Urğirnuna, which they seize and lacerate as a result. Specifically, the foreign sorcerer produces in sequence: 1) a big carp; 2) a ewe with its lamb; 3) a cow with its calf; 4) an ibex and a wild sheep; and 5) a young gazelle. The wise witch, on the other hand, counters these creations correspondingly with 1) an eagle; 2) a wolf; 3) a lion; 4) a mountain leopard; and 5) a tiger and another kind of lion. In this way, all of Urğirnuna's creatures are eliminated, and Sağburu wins the contest. The defeated sorcerer begs for his life, but Sağburu kills him in punishment for his black and destructive magic. When Ensuhgirana hears this, he openly acknowledges Enmerkar's superiority ${ }^{8}$.

Another example comes from an ancient Egyptian fantastic novella concerning the adventures of a legendary magician, Setne Khaemwaset, and his son Si-Osire. The Demotic Egyptian text is preserved on a papyrus of the Roman period (1st century

Alster (1973: 106-107); Cohen (1973: 16-17, 22); Alster (1995: 2316, 2324); Vanstiphout (1995: 6-7, 11-12); Konstantakos (2008: 74-78).

${ }^{6}$ See Hallo (1963: 167-168); Cohen (1973: 1-14); Jacobsen (1987: xii, 277); Vanstiphout (1995: 6); Klein (1995: 846-847); Alster (1995: 2315-2316, 2322); Michalowski (1995: 2284); Black (1998: 23-24, 164-165); Vanstiphout (2003: 1); Black - Cunningham - Robson - Zólyomi (2004: xlvii-1); for more bibliography, see Konstantakos (2008: 69).

7 There is no consensus among experts as to the exact nature of the thing thrown into the water, due to the semantic ambiguity of the corresponding Sumerian logogram. Vanstiphout (2003: 23, 42-43, 48) and Black - Cunningham - Robson - Zólyomi (2004: 4, 9) interpret it as "fish spawn", which is evidently used as raw material for the magical formation of the animals. According to Berlin (1979: 54-57, 88-89), the logogram means rather a copper object, which is clearly imagined here to possess miraculous powers. This is employed somewhat like the magic wand of fairytales, as a medium for the sorcerers' magical acts.

${ }^{8}$ For the text of the magical contest (vv. 225-273), see Berlin (1979: 54-59); Vanstiphout (2003: 42-45); Black - Cunningham - Robson - Zólyomi (2004: 9-11). 
A.D.), but the narrative may well go back to earlier times. The central personage is based on a historical figure, Khaemwaset, a son of pharaoh Ramses II (ca. 1279-1213 B.C.) and High Priest of Ptah at Memphis, who became famous as a polymath and a pioneer archaeologist. Legends about Khaemwaset and his skills in wizardry may have started to form already in the centuries after his death. Other papyri show that a cycle of literary narratives about the magician Setne was fully developed by the beginning of the Ptolemaic period. The novella about Setne and Si-Osire may have formed part of them. Further, certain Realien of the storyline (e.g. the conflict between Egypt and the Nubian kingdom of Kush) point to historical circumstances of the Saïte period (7th and 6th century B.C. $)^{9}$.

In the Egyptian story, the magical contest is set again in a context of broader interstate conflict. One day a stranger from Kush (the hostile Nubian kingdom at the south of Egypt) appears in the court of Ramses II at Memphis and proposes an impossible task before the pharaoh and his assembled council: a wise Egyptian must read the sealed letter, which the stranger has brought along, without opening it. If no one in the country is up to this feat of divination, the stranger will return to Nubia and report there the humiliation of Egypt. The pharaoh agonizingly searches for such a clairvoyant person; finally, Setne's young son, the child prodigy Si-Osire, undertakes the task and magically reads the closed epistle. As it transpires, its text narrates a contest of wizardry which took place 1500 years earlier, between a sorcerer from Kush and an Egyptian wise priest named Horus son of Paneshy. The chieftain of Kush, a sworn enemy of Egypt, had ordered his sorcerer to harm and shame the Egyptian pharaoh by means of his miraculous powers. However, Horus of Paneshy countered the Kushite's artifices and protected the Egyptian sovereign.

In the end, the two magicians confronted each other in the pharaoh's court and held a competition of witchcraft. The Kushite made a spell of magical writing and caused a fire to break in the court. Immediately, the Egyptian spoke another magical formula and brought about a heavy rainstorm above the fire, thus extinguishing the flames. Then the Nubian sorcerer created a thick cloud over the court, which entirely hid the light. Horus of Paneshy recited a counter-spell to the sky and made the mist vanish. The Kushite conjured up a huge vault of stone over the pharaoh and his nobles, so as to cut them off from their land. The Egyptian sage fashioned a papyrus boat which enveloped and carried the vault away, sailing in the sky. Finally, the Nubian enemy took the shape of a wild gander and attempted to fly away; but Horus of Paneshy pronounced a spell against him and made him turn over on his back, while a fowler with a sharp knife appeared above the gander, ready to slaughter it. The Kushite's mother, herself an accomplished witch, arrived at that moment in the form of a goose, so as to assist her son. By means of a magical recitation, the Egyptian wizard made her also lie on her back, with a fowler standing above her. After these incidents, mother and son were forced to capitulate, and the victorious Horus made them swear that they would

\footnotetext{
${ }^{9}$ See Griffith (1900: 13-15, 41-42, 67-68); Pieper (1931); Sauneron - Yoyotte (1952: 193-194); Brunner-Traut (1965: 296-301); Bresciani (1975); Lichtheim (1980: 125-126); Grimal (1994: 99-101); Hoffmann (2000: 207-213); Simpson (2003: 453-454, 470-471); Bresciani (2007: 882-883); Konstantakos (2008: 33, 115-116, 136-139).
} 
not come back to Egypt for 1500 years. At this point, the narration of the letter ends. Si-Osire further reveals that the Nubian newcomer is that same Kushite sorcerer, who now returns to harm Egypt after the expiration of his oath. As for Si-Osire himself, he is a reincarnation of Horus of Paneshy, who was reborn as Setne's son in order to protect his homeland once more ${ }^{10}$.

In the Egyptian novella, the agon entails again the creation of various physical entities by means of witchcraft. The things brought forth by the Egyptian sage always prove stronger and capable of eliminating the fabrications of his Nubian adversary; in this way, the Egyptian wins. Admittedly, the pattern is not always followed with absolute faithfulness, as in the Sumerian epic. In the second stage of the competition, Horus of Paneshy does not create anything to counter the Kushite's mist, but simply dissolves it by means of a spell. Also, in the last phase the Nubian chooses to metamorphose himself into a bird, thus disrupting the sequence of magical creations with a feat of personal transformation. The Egyptian priest, nonetheless, counters him again by producing an autonomous and more powerful figure.

A third and briefer ancient example of the same pattern comes from the Hebrew book of Exodus (7.8-12). The episode occurs during the famous contest in which Moses and Aaron, the leaders of the Hebrew people, confront the magicians of Egypt in the pharaoh's court. The two Hebrew brothers appear before the Egyptian monarch, who asks them to show him a miracle. Aaron, following the instructions given beforehand by the Lord, throws down his rod, which turns into a snake. The pharaoh then calls his wise men and sorcerers, who try to duplicate the same marvel; they all cast down their own rods, which are similarly transformed into snakes. However, the snake created by Aaron proves stronger than the serpents of his Egyptian opponents and swallows them all up ${ }^{11}$.

In this case, the animals produced by the opposed characters belong to the same species. However, the creature of the winning adversary turns out to be more powerful than the likes of it which are produced by the losers. Thus, the pattern of gradation is retained, even though it is now due to the comparative increase of strength between specimens of identical genus, rather than to the clash of a weaker with a stronger kind of animal. The same variation occurs in some folktales about magical metamorphoses. For example, in a story collected by the Brothers Grimm, the young hero flees as a sparrow, and the master thief also takes the shape of a sparrow to pursue him; the two of them struggle in mid-air, but the master loses and falls into the water, where he transforms himself into a fish. The young man becomes another fish, and the two of them hold a second contest, in which the master is beaten again. In this sequence as well, the species of the creatures remains the same; what differs is the strength of the conflicting representatives of each species, as demonstrated by their performance

${ }^{10}$ For text and translations of this novella, see Griffith (1900: 42-66, 142-207); Brunner-Traut (1965: 192-214); Lichtheim (1980: 138-151); Maspero (2002: 119-137); Simpson (2003: 472-489); Bresciani (2007: 894-908). For the episode of the magical contest in particular, see Griffith (1900: 62-65, 194-203); Brunner-Traut (1965: 209-212); Lichtheim (1980: 148-150); Maspero (2002: 134-136); Simpson (2003: 486-488); Bresciani (2007: 905-907); cf. Penzer - Tawney (1924-1928: III, 203); Anderson (2000: 110).

${ }^{11}$ On the connections between this episode and the folktales of magical transformation, cf. Bolte Polívka (1913-1932: IV, 107); Gunkel (1987: 116-117). 
in the air and water contests ${ }^{12}$. Other magical transformation stories with similar confrontations (a bull struck down by a stronger bull, an ass bitten hard by a fiercer ass, a hawk torn apart by a more valiant hawk, a black mare struggling with a bay mare) are known from the Indian and the Gaelic Scotch popular traditions ${ }^{13}$.

In Hellenic mythology there are also traces of the magical transformation contest, but they are limited to the standard pattern which predominates in modern folk traditions: namely, the combat in which the competitors transform themselves into the various beings. The most straightforward example is the story about Zeus' erotic pursuit of Nemesis, included in the cyclical epic Cypria and summarily retold in the compilations of later mythographers (Apollodorus' Bibliotheca and Pseudo-Eratosthenes' Catasterismi). It also seems that some version of the same myth was burlesqued or comically reworked in Cratinus' Nemesis, a comedy produced in Athens in the late 430s. The Cypria offers the most expanded and detailed form of the saga ${ }^{14}$. Zeus was amorously chasing Nemesis, but she was averse to his sexual intentions and ran away. In the course of her flight, Nemesis took the form of various beasts; she became a fish in the sea and swam through the Ocean's stream; then she changed herself into many kinds of animals on the land, in order to escape ${ }^{15}$. In the end, the goddess was transformed into a bird, the species of which is variously given in the ancient sources. According to the Cypria (fr. 8 Davies $=10$ Bernabé $=11$ West, from Philodemus, On Piety B 7369 Obbink) and Apollodorus (Bibliotheca 3.10.7), Nemesis became a goose. A later variant, given in an apparently interpolated passage in Pseudo-Eratosthenes' Catasterismi, has her turn into a swan ${ }^{16}$. In either case, Zeus assimilated himself to the

${ }^{12}$ Brothers Grimm, Kinder- und Hausmärchen no. 68 ("De Gaudeif un sien Meester"); see Rölleke (2007: I, 363). The rest of the tale conforms to the usual pattern of weaker versus stronger animal: the master thief becomes a cock; the young man turns into a fox and bites the cock's head off.

${ }^{13}$ See Penzer-Tawney (1924-1928: III, 195) for a story from the Sanskrit collection Kathāsaritsāgara ("Ocean of the Streams of Story") by the Brahmin Somadeva (11th century A.D.); Campbell (1860: 422423) and Clouston (2002: 217-218) for a Gaelic folktale from the island of Barra in the Outer Hebrides.

${ }^{14}$ Cypria fr. 7 and 8 Davies $=$ fr. 9 and 10 Bernabé $=$ fr. 10 and 11 West (from Ath. 8.334b-d and Philodemus, On piety B 7369 Obbink). Further sources are Apollod. Bibl. 3.10.7; Ps.-Eratosth. Cat. 25 (p. 31 Olivieri, pp. 142-143 Robert) citing Cratinus, Nemesis, test. ii Kassel - Austin. On this myth and its variant versions, see most notably Cook (1914: 279-280); Ninck (1921: 140-141); Severyns (1928: 267-271); Herter (1935: 2342-2346); Kerényi (1939: 161-177); Lesky (1947: 122); Jouan (1966: 147-151); Luppe (1974); Forbes Irving (1990: 187-191); Gantz (1993: 9, 319-320, 855); Buxton (2009: 162, 168-169); Bakola (2010: 168-172, 220-222, 251); Storey (2011: 321-325); Henderson (2012: 1-6); West (2013: 72, 80-83).

${ }^{15}$ A similar myth seems to have developed around Metis; in a few later sources, she is also said to have transformed herself into many shapes in order to avoid having sex with Zeus. See Apollod. Bibl. 1.3.6; Sch. Hom. Il. 8.39a (II, p. 307 Erbse); Sch. Hes. Th. 886 (p. 110 Di Gregorio); Ninck (1921: 141); Forbes Irving (1990: 184-188, 190).

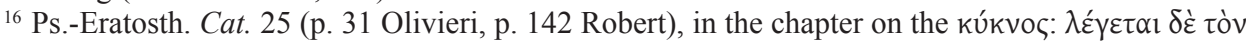

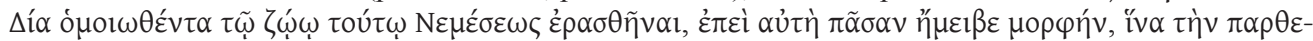

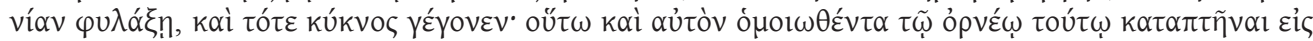

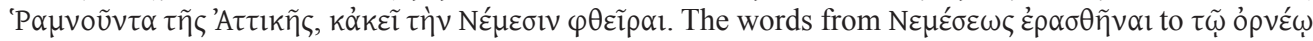
$\tau o u ́ \tau \omega$ are absent from one of the most important codices and have therefore been considered as a later addition to the original text; see Olivieri (1897: 31); Herter (1935: 2343); Luppe (1974: 202); Gantz (1993: 855). Still, they represent a notable variant, which some Greek scholiast or myth compiler must have concocted, at however late an age. 
same species of bird, becoming respectively a gander in the former version and a male swan in the latter one ${ }^{17}$. In this form, the great god finally managed to mate with the metamorphosed and bird-like Nemesis ${ }^{18}$.

The extant testimonia of this Greek myth, as surveyed above, do not mention any metamorphoses of Zeus before his final avian shape. This marks a divergence from the typical pattern of the magical transformation combat, in which both opponents successively assume the appearance of various creatures, while one of them hunts the other. Of course, it must be borne in mind that only small fragments have survived from the relevant section of the Cypria. It is possible that in this epic poem Zeus was also imagined to be undergoing the same or analogous changes of form as Nemesis, and to be emulating her shape-shifting feats throughout the duration of his amorous pursuit of her. This might have been made clear in the lost surrounding narrative of the Cypria episode or in the verses that followed immediately after the short citation preserved by Athenaeus ${ }^{19}$. In any case, at least the ending of the mythical story conforms to the folktale scheme: both contestants transfigure themselves, and Zeus' metamorphosis proves mightier than that of Nemesis, since he manages to overcome and rape her. The transformation of both adversaries into animals of the same species, which only differ as to their relative strength, is known from various folkloric specimens, as has been amply documented above in connection with the contest of the Exodus.

In the myth of Nemesis the magical contest is closely joined to an erotic pursuit. The same combination of motifs occurs in some modern folktales and popular ballads; in these latter cases the untamed girl, just like Nemesis, turns herself into various animals or things while she tries to avoid her suitor; but the lover runs after her and takes each time the form of a superior creature, until the two of them are finally united. Such a storyline occurs e.g. in Scottish, French, and South Slavic ballads, as well as

${ }^{17}$ For the mating of male with female swan, see the text of the Catasterismi quoted in the previous footnote. For Zeus-gander copulating with Nemesis-goose, see Cypria fr. 11 West (the latest edition, West

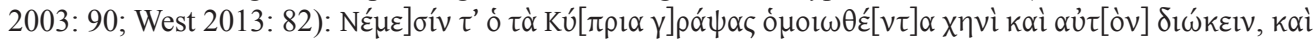

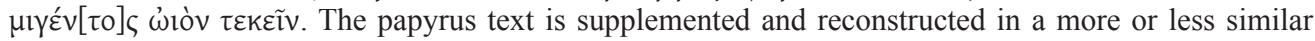
manner by earlier editors, without significant changes in the overall meaning; see Luppe (1974: 196-201); Luppe (1975); Davies (1988: 38); Bernabé (1996: 50); cf. Henderson (2012: 3).

${ }^{18}$ The transmitted text of Apollodorus (Bibl. 3.10.7) presents at first sight an odd combination: NE-

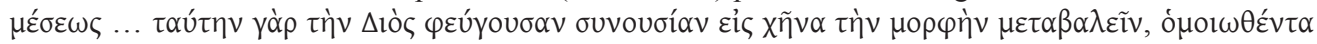

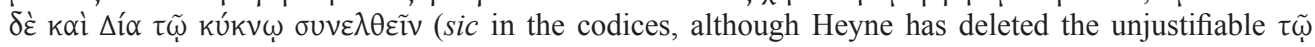
before $\kappa u ́ \kappa v \omega$, and his emendation has been adopted by subsequent editors). The same version is faithfully reproduced in Sch. Tz. ad Lyc. 88 (p. 49 Scheer), which obviously depends on Apollodorus' text as we know it. With this formulation, Nemesis is metamorphosed into a goose, but Zeus takes the form of a swan in order to copulate with her; the two divinities assume different shapes, and yet this prevents neither their sexual union nor the birth of an egg from it. However, Luppe (1974: 194-196) has proposed a

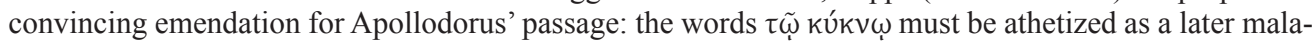
droit interpolation by a scribe who did not understand the meaning of the text and was led astray by other well-known legends regarding Zeus' transformation into a swan. The authentic text of the Bibliotheca

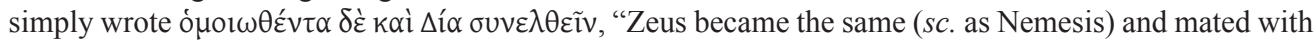
her". With this ingenious correction, Zeus changes himself into the same animal species as Nemesis the goose, i.e. into a male gander, and the situation becomes identical to the plot of the Cypria. Cf. similarly Papathomopoulos (2010: 158); West (2013: 82-83).

${ }^{19}$ Cf. Herter (1935: 2343); Kerényi (1939: 161); Henderson (2012: 2); West (2013: 83). 
in Russian and Tartar Siberian folktales. For example, the indomitable woman may become a bream and fall into the sea, or a small bird that flies through the air, or a hare that runs on the hill, while the lover pursues her respectively as a large pike, a vulture, or a greyhound. She turns into a grey mare, but he takes the form of a saddle and sits upon her; and so forth, with many further imaginative combinations ${ }^{20}$. A very close parallel to the adventure of Zeus and Nemesis is provided by a Scottish folk ballad. In some stanzas of this song, the bride and the groom are metamorphosed into pairs of identical animals, but the male specimen of the pair proves stronger than the female one and thus accosts or mates with her. So, when the girl becomes a duck in a pool, the suitor approaches her as a drake; she flies up as a turtledove, and he turns into another dove and pairs with her ${ }^{21}$. These confrontations are not far from those of goose and gander or male and female swan in the Greek myth.

More distant echoes of the same folktale pattern may be discerned in other stories of the Hellenic mythological tradition, which concern divinities with shape-shifting abilities, such as Thetis, Proteus, Nereus, and the river-god Acheloos. Occasionally, the same powers of metamorphosis are also granted to mortal figures, such as Periklymenos the son of Neleus. Any one of these shape-shifters, when involved in a struggle against a valiant hero, may transform himself into a long series of animals or natural elements, in order to fight his opponent or elude the hero's grasp. For example, Proteus, the "old man of the sea", when seized by Menelaus in his cave at the seashore, tries to escape by turning successively into a shaggy lion, a snake, a leopard, a boar, water, and a tall tree; but Menelaus holds unflinchingly onto him, until the marine daemon yields and reveals his secrets. Similarly, when Peleus captures Thetis with amorous intentions, she assumes the shapes of many beings (wind, fire, water, beast, bird, tree, lion, tigress, fish, or snake, depending on the source), in order to free herself; but the hero does not let her go, until Thetis resumes her normal appearance and consents to marry him. The same scheme is repeated in the struggles of Heracles against Nereus, Acheloos, and Periklymenos. In every case, Heracles' adversary takes sequentially the forms of various creatures (wild animals of the land, birds, serpents, insects, or even natural elements such as water and fire); but the strong hero always manages to win, killing in the end the mortal Periklymenos or constraining the divine figures (Nereus, Acheloos) and obliging them to admit defeat ${ }^{22}$.

${ }^{20}$ The combinations include e.g. a rose and the bee that sucks on it; a quail and the huntsman that captures it; a carp and the angler that fishes it up; a star and the cloud that muffles it; a dead corpse and the earth that envelops it; a griddle and a cake baked on it; a silk bed-sheet and a green covering placed upon it etc. See Child (1904: 77-78); Bolte - Polívka (1913-1932: II, 68-69); Cosquin (1922: 584-585). Cf. also the remarks of Herter (1935: 2346) and Forbes Irving (1990: 190).

${ }^{21}$ See Child (1904: 78).

${ }^{22}$ Proteus and Menelaus: see Hom. Od. 4.415-419, 454-461. Peleus and Thetis: see Pi. Nem. 4.62-65; Soph. fr. 150 Radt; Apollod. Bibl. 3.13.5; Ov. Met. 11.238-265; Qu. Smyr. 3.618-624; Sch. Pi. Nem. 3.60 and 4.101a (III, pp. 51 and 81-82 Drachmann); Sch. Tz. ad Lyc. 175, 178 (pp. 85, 88 Scheer). Nereus and Heracles: see Pherecydes, FGrHist 3 F 16a (= Sch. Ap. Rh. 4.1396-99b, p. 315 Wendel); Apollod. Bibl. 2.5.11. Acheloos and Heracles: see Soph. Tr. 10-27; Ov. Met. 9.31-88; Sen. Herc. Oet. 495-498; Hyg. Fab. 31. Periklymenos and Heracles: see Hes. fr. 33(a) and 33(b) Merkelbach - West; Apollod. Bibl. 1.9.9; Ov. Met. 12.556-572; Sch. Ap. Rh. 1.156-60a (pp. 20-21 Wendel); Eust. Comm. ad Od. pp. 1685-1686. Generally on these myths and the ancient sources transmitting them, see Ninck (1921: 138-180); Frazer 
In all these mythical adventures, however, only one of the opponents in the combat actually changes forms; the other one (Peleus, Menelaus, or Heracles) keeps his human appearance throughout and uses his heroic strength in order to fight the shapeshifter or imprison him in his tight hold. This is an important difference by comparison to the other tales about magical contests examined above. The stories of Proteus, Thetis, Neleus, Periklymenos, and Acheloos offer no fully-fledged magical contest with mutual transformations of both adversaries, as is typical in the folktale tradition ${ }^{23}$.

This divergence aside, it is significant that most of these mythical shape-shifters are connected to the element of water, given that they are marine divinities or river spirits; even the mortal Periklymenos is said in most of the sources to have received his powers of metamorphosis as a gift from Poseidon, the god of the sea. The selftransformative capacities of all these figures reflect in essence the fluidity and mutability of water, par excellence the substance that has no fixed form or outline but takes the shape of any particular container ${ }^{24}$. In this respect, it is interesting to recall the wizardry contest of the age-old Sumerian epic. The witch Sağburu and the evil magician Urğirnuna have their competition at the bank of the Euphrates, and the river itself

(1921: I, 84-85, 222, 256-257; II, 67-68); Lesky (1947: 120-127); Rose (1958: 293-294); Forbes Irving (1990: 171-184); Gantz (1993: 28-29, 184-185, 229, 405-406, 432-433, 663-664); Anderson (2000: 110111); Hansen (2004: 38, 57, 304, 319); Buxton (2009: 37-38, 84-90, 168-171, 174-175); West (2013: 72).

${ }^{23}$ In classical mythology and literature, there are also other narratives which revolve around personages with shape-shifting abilities. For example, Mestra, Erysichthon's daughter, is granted by her divine lover Poseidon the ability to change forms, and uses her gift in order to procure food for her insatiable father. She metamorphoses herself into various animals (mare, bird, cow, deer), is sold every time in her animal form to a customer, and then resumes her human appearance and returns home again (Ov. Met. 8.852-874; cf. Ninck 1921: 144-145; Forbes Irving 1990: 173; Buxton 2009: 171). This story presents similarities to the earlier part of the folktale type ATU 325 ("The magician and his pupil", see above), before the magical combat of the two protagonists (see Cosquin 1922: 601-604; Scherf 1995: II, 1438). Zeus also turns himself into diverse beings, in order to seduce his many ladyloves (Europe, Danaë, Alcmene, Callisto etc.; see Hansen 2004: 38, 333-334; Buxton 2009: 77-84, 126-130, 148-150, 159-160; Konstantakos 2013). A comic parody of this mythical scheme is found in Ar. Nu. 346-355: the Clouds are able to assume the shape of any creature, so as to reflect the particular vice of the man they encounter each time; thus, they become centaurs when they see a shaggy and lustful pederast, wolves in front of a greedy thief of public funds, deer upon looking at a cowardly deserter, and women as soon as they behold a notorious effeminate. Here the popular motif of shape-shifting is cleverly adapted to the satirical purposes of Old Attic Comedy. More myths of this kind (concerning the Telchines, Athena, Dionysus, Poseidon, Triton, Morpheus, Empousa, and many other figures) are surveyed by Ninck (1921: 139, 142143, 146-157, 161-180); Forbes Irving (1990: 43, 171-174, 178, 191-194); Hansen (2000: 7-16); Hansen (2004: 37-38, 302-304); Buxton (2009: 29-37, 50-53, 124, 150-151, 157-177). In all these stories, however, the protagonist is the sole shape-changer and alters his form "in isolation", not as part of a contest or competition against an equally self-metamorphosing opponent. In most cases, we do not even find the broader context of a fight against a non-magical but tenacious adversary (as in the myths of Proteus, Nereus, Thetis, Periklymenos, and Acheloos). Therefore, all these narratives are simply examples of the widespread fantastic concept of the "shape-shifter" (cf. Forbes Irving 1990: 171-194 and Buxton 2009: 168-175), a favourite motif in many mythical and folk traditions; but they are not relevant to the specific pattern of the magical transformation contest analyzed in this essay.

${ }^{24}$ See Ninck (1921: 138-180); Frazer (1921: II, 68); Herter (1935: 2346); Lesky (1947: 112, 122 , 125-126, 137); Hansen (2004: 38, 304, 319); Buxton (2009: 86, 88, 174-175). Some reservations are expressed by Forbes Irving (1990: 173-174, 179), but see Buxton (2009: 86, 88). 
plays an essential part in their magical fabrications; each one of the contestants throws an object of witchcraft into the river nearby and then draws out the miraculously created animals. Once again, the element of water is present, auxiliary and determinative in a feat of marvellous metamorphosis. The magic objects thrown into the river are clearly supposed to be transformed into the different creatures that are produced each time. The water of the Euphrates presumably serves as a medium for this transmutation and channels the supernatural powers of the two magicians, so as to achieve the desired effect $^{25}$. Apparently, water and magical metamorphosis have been closely connected from very ancient times, ever since the dawn of mythical thinking.

All the classical Greek specimens surveyed above exemplify the version of the tale-type which is commonest in folklore; the heroes assume themselves the shapes of different creatures. Admittedly, no known ancient Greek text contains a straightforward instance of the other, alternative variation: viz. the contest of magical creations, in which the adversaries produce conflicting beasts or elements (rather than being transformed into them), as happens in the Near-Eastern specimens (the Sumerian epic, the Egyptian novella, and the Exodus). Nonetheless, one Hellenic narrative may bear certain influences or echoes from this latter variant story-pattern.

The narrative in question is included in the so-called Alexander Romance (also known as "Pseudo-Callisthenes", from the name of its putative author), a fictionalized biographical novel about the life and exploits of Alexander the Great. The story presents a contest of wit and wisdom between Alexander and the Persian king Darius III, the two great adversaries in the war for the domination over the empire of the East. Of course, in this particular episode of the romance all the magical motifs of the traditional folktales have been deflated and rationalized; the action is wrenched out of the world of miracles and transposed to a realistic pseudo-historical atmosphere. Yet the Greek narrative seems to be modelled on a scheme which replicates the basic structure and the sequence of events that are familiar from the tales about contests of magical creation. It may thus be hypothesized that such tales have inspired the story about Alexander or contributed ideas for its formation. The following section is dedicated to the analysis of this unique piece of ancient Greek lore, which calls for detailed comparison with the known ancient examples of magical combats.

\section{SYMBOLIC METAMORPHOSES: THE CONFRONTATION OF ALEXANDER AND DARIUS}

There is considerable scholarly controversy concerning the date of composition of the Greek Alexander Romance. Several researchers believe that the earliest version of this work, as we know it, was first compiled in the Roman period, around the 3rd

${ }^{25}$ The element of water is also associated with some of the protective spells used by Horus of Paneshy in the Egyptian novella of Setne. Horus creates beneficial rain to quench the Nubian sorcerer's destructive fire; he removes the isolating stone vault by means of a papyrus boat, similar to the vessels sailing on the Nile. Egypt owed its life and prosperity to this great river, which traverses and irrigates it. Suitably, therefore, the magical salvation of the land comes from the power of life-giving water. 
century A.D. ${ }^{26}$. Other experts argue for a dating of the prototypical romance in the Hellenistic period and read it as a product of the cultural milieu of Ptolemaic Alexandria $^{27}$. In any case, Pseudo-Callisthenes' text has been based on a number of earlier sources, absorbing and combining large chunks of them, in order to put together the narrative of Alexander's exciting adventures and tragic death ${ }^{28}$. Many of these individual components were current already in the Hellenistic period, given that independent fragments of them are preserved in Hellenistic or early Roman papyri.

One of these Hellenistic source-works, from which much material has flown into the Alexander Romance, was a collection of fictitious epistles supposedly exchanged between Alexander, the Persian king Darius, and other personages involved in the war between Macedon and the Asiatic empire. This composition seems to have been a kind of "epistolary novel" (Briefroman), which set forth the story of Alexander's Asian expedition in the form of a series of personal letters; these were presented as written by various historical figures, who narrated the main events from their own viewpoints ${ }^{29}$. Two papyri (one of them, P.Hamb. 129, dating from the 2nd century B.C.) preserve fragments from collections or anthologies of such fictional missives, including letters of Alexander and Darius which also occur in the Alexander Romance. It is thus clear that one or more novelized epistolary works of this kind were circulating in the mature Hellenistic age ${ }^{30}$. A number of interconnected letters from such a Briefroman have been taken over and incorporated into Pseudo-Callisthenes, at suitable points of the narrative.

The episode to be discussed here is formed by such an exchange of missives between the two main adversaries, Alexander and Darius. In Pseudo-Callisthenes' narrative, this episode comes shortly after the start of Alexander's expedition. The young and ambitious Macedonian has just conquered Tyre and the Syrian inland and is preparing to advance further into Asia (1.36.1). At this juncture, Darius sends envoys to Alexander's camp, bearing a triad of symbolic gifts: namely, a whip, a ball, and a chest full of gold. The envoys also bring a letter, in which the Iranian despot, among many arrogant statements and threats, expounds the allegorical meaning of the afore-

${ }^{26}$ See Fraser (1972: I, 677; II, 946); Merkelbach (1977: 90-91); Gual (1977: 10, 15-17, 23); Fraser (1996: 221-223); Stramaglia (1996: 106); Jouanno (2002: 13-16, 26-28, 34) with further references.

${ }^{27}$ For the fullest and most cogent argumentation, see Stoneman (1991: 8-10, 14-17); Stoneman (2007: xxviii-xxxiii, 1, liii-lvi); cf. Whitmarsh (2013: 171-172, 185-186). An intermediate position is advocated by Callu (2010: 23-31), who places the creation of Pseudo-Callisthenes in the early Roman age (between 60/50 B.C. and A.D. 16); but see Konstantakos (2015: 130, 133) on the flaws of his thesis.

${ }^{28}$ On the sources of the Alexander Romance see the surveys of Fraser (1972: I, 677-680: II, 946950); Merkelbach (1977); Gual (1977: 17-24); Stoneman (1991: 9-14); Fraser (1996: 210-220); Jouanno (2002: 17-26); Stoneman (2007: xxv-xxviii, xliii-1).

${ }^{29}$ The extent, fullness, and historical fidelity of this Hellenistic "epistolary novel" are debated. See in general van Thiel (1974: xiii, xvi, xxi-xxiv); Merkelbach (1977: 11-15, 18, 48-55, 230-252); Gual (1977: 19-20); Stoneman (1991: 9-11, 20); Bounoure - Serret (1992: xvii-xviii, xxiv); Holzberg (1994: 6-7, 49, 52); Stramaglia (1996: 106-113); Fraser (1996: 216-218); Franco (1999: 49-50); Rosenmeyer (2001: 169-192); Jouanno (2002: 19-21, 42-44, 142-144, 176, 193-194); Stoneman (2007: xxvi-xxviii, xxxiii, xliv-xlv, liv, lxxvii-lxxviii); Giuliano (2010); Whitmarsh (2013).

${ }^{30}$ See Merkelbach (1977: 11, 55); Stramaglia (1996: 108); Jouanno (2002: 19-20, 43); Cavallo Maehler (2008: 69); Callu (2010: 28); Giuliano (2010: 216-219, 222). 
mentioned objects. The whip is meant to indicate that young Alexander is still in need of being disciplined and educated. The ball signifies that Alexander is merely a child, fit only for playing with his age-mates, not for undertaking military ventures. As for the chest, this contains enough gold to finance the safe return of all the Macedonian soldiers to their homeland, even if Alexander does not possess the monetary means to ensure their journey back (1.36.1-5) ${ }^{31}$.

Alexander is not intimidated by his opponent's bragging tone. He responds to Darius with a letter of his own (1.38), in which he gives a diametrically different interpretation of the symbolic presents and manipulates their meaning to his own advantage. In this alternative reading, the whip represents the weapons by which Alexander will beat the Persians and make them submit to his authority. The ball indicates that Alexander will dominate the world, which is similarly spherical in shape. Lastly, the coffer of gold foreshadows that Darius will be defeated and forced to pay tribute to the Macedonian conqueror $(1.38 .7)^{32}$. This is the outline of the narrative in the oldest and most authentic Greek text of Pseudo-Callisthenes ${ }^{33}$.

A specific literary model has often been proposed for the story of Darius' gifts to Alexander. This is the legend about the riddling presents which were sent by the Scythians to another Persian king, Darius I, while the latter was conducting his notorious military campaign against Scythia. According to Herodotus (4.131-132), the Scythian chieftains sent an envoy to deliver to Darius a bird, a mouse, a frog, and five arrows, without any explanatory message, apart from an exhortation that the Persians

${ }^{31}$ See the earliest Greek text of the Alexander Romance in codex A (Kroll 1926: 40-41; Stoneman

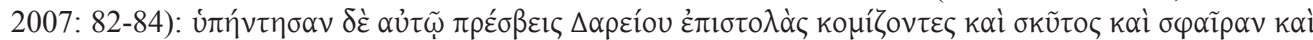

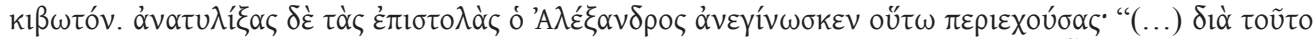

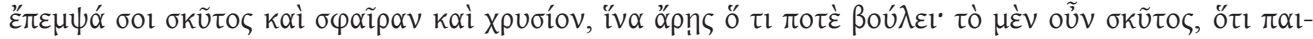

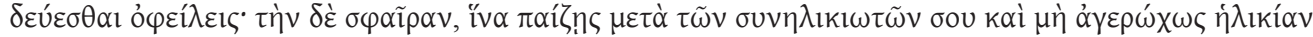

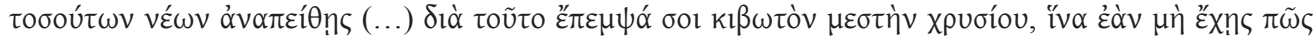

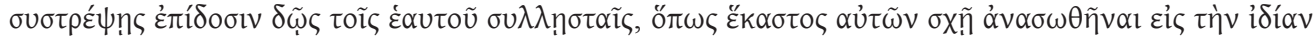
$\pi \alpha \tau \rho i ́ \delta \alpha "$.

${ }^{32}$ Once again the text of the earliest version of A is cited (Kroll 1926: 43; Stoneman 2007: 88-90):

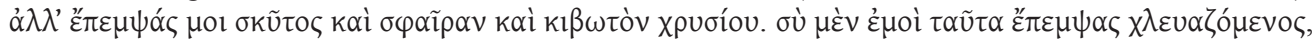

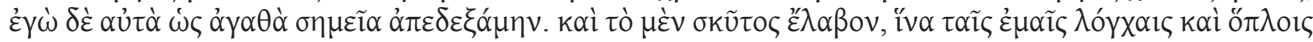

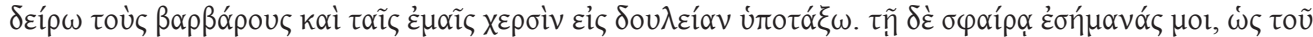

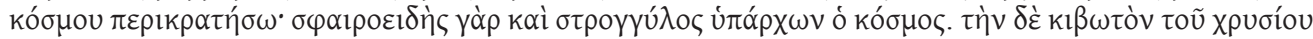

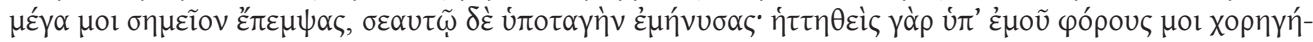

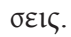

${ }^{33}$ Later versions and offshoots of the Alexander Romance (especially in the late Medieval and Modern Greek, the Medieval Latin, as well as the Syriac and later Muslim traditions) offer variant forms of the episode; they diversify the list of symbolic gifts, expand it with additional items, or alter some of the interpretations. For detailed discussion, see Konstantakos (2015). Nevertheless, the synopsis given above, apart from reflecting the earliest known Greek text of codex A, also conforms substantially to the other representatives of the earliest recension (the Latin translation of Julius Valerius and the Armenian version), as well as to most of the Greek redactions of late antiquity and early Byzantine times ( $\beta$, L, and most manuscripts of $\gamma$ ). This synopsis is therefore sufficient for the purposes of the comparative analysis attempted in this essay. For a general study of the episode, see also Merkelbach (1977: 51, 118); Eckard (1997); Rosenmeyer (2001: 177-180); Jouanno (2002: 142, 193, 203-204, 224); Stoneman (2007: 553554); Whitmarsh (2013: 176-177). 
should guess the meaning of these items. At first, Darius took the objects to signify that the Scythians were subjecting themselves to his power. The mouse would represent earth and the frog water - "earth and water" being the standard tokens of submission demanded by the Persians from subjugated peoples. Further, the arrows and the bird (which Darius took for a symbol of horses) were emblems of the Scythians' means of might in battle, which would also be surrendered to the Persian king. By contrast, the Iranian nobleman Gobryas interpreted the gifts as a threat: namely, unless the Persians became birds to fly up to heaven, or mice to hide under the earth, or frogs to leap into the lakes, they would not escape the Scythian arrows. In the alternative version of Pherecydes (FGrHist 3 F 174, from Clement of Alexandria, Stromata 5.8.44), the series of symbolic objects also includes a plough, and the conflicting explanations are given by two Persian military officials, named Orontopatas and Xiphodres. Otherwise, the structure and meaning of the narrative remain essentially the same. The chiliarch Orontopatas argues for the reading favourable to the Persians: the Scythians intend to hand over their habitations (mouse), waters (frog), air (bird), weapons (arrow), and entire land (plough). Xiphodres, by contrast, suggests the same menacing interpretation as Gobryas in Herodotus, and adds that the Persians cannot dominate the Scythian land (the symbolism of the plough). In both variants, the second, ominous explanation is finally proven correct. As is well known from Herodotus, the Persian army was in the end forced to retreat and failed to conquer Scythia ${ }^{34}$.

There are obvious analogies between this legend and the episode from the Alexander Romance ${ }^{35}$. The Persian king, called in both narratives Darius, is brought into confrontation with the leader or leaders of an enemy power at the northern borders of his empire (Scythia or Macedonia); this latter power is destined to prove stronger and defeat the Achaemenid army. In both cases, a group of riddling gifts, which collectively convey a symbolic message, are sent by one of the opposed parties to the other. In both stories, two diametrically contrasted interpretations of the meaning of the gifts are juxtaposed; one of these interpretations is propitious to the Persians, while the other is inimical to them, in that it signifies their defeat at the hands of the enemy force. As in Herodotus, so also in the episode of Pseudo-Callisthenes it is King Darius who rashly gives the explanation favouring his own side. But Darius' view is soon revealed to be mistaken, because the hostile power overcomes the Persians and puts them to flight.

Nevertheless, it must be stressed that the legend of the Scythians' gifts, whether in its Herodotean or in its Pherecydean form, does not suffice by itself to explain all the peculiar characteristics of Pseudo-Callisthenes' episode. The ambiguous symbolism of the dispatched objects is indeed the fundamental common element of the two tales; it is precisely this ambiguity that allows the two adversaries to offer opposite explanations concerning the metaphorical value of the presents. In a way, the ambivalent gifts constitute a kind of visual riddle or conundrum with a hidden meaning, which is

\footnotetext{
${ }^{34}$ On this story and its variants, see most notably West (1988); Schubert (2010: 93-116); and Konstantakos (2015: 138-142) with further references.

${ }^{35}$ See Eckard (1997: 248); Franco (1999: 71); Rosenmeyer (2001: 177); Jouanno (2002: 31, 53 54); Stoneman (2007: 554); Anderson (2012: 95); and Konstantakos (2015: 138-144) for a detailed comparison.
} 
differently expounded by the two solvers ${ }^{36}$. However, the layout of the contrasting interpretations is quite different in the two narratives. In the story of Alexander, notably, the opposed solutions given by the Persian and by the Macedonian king are structured on a pattern of escalation; combined together, they form a kind of scale, a climactic progress from weaker to stronger. Darius' explanation, the first one to be proposed, marks every one of the items as a sign of weakness and submission: the whip alludes to the chastisement of a disobedient boy; the ball means a child's play; the chest of gold points to the Macedonians' lack of funds. By contrast, the following solution, as offered by Alexander, turns each one of these objects into a much more forceful entity, an emblem of power and victory. Now the whip represents the strength of weapons and military triumph; the ball indicates domination over the whole world; and the coffer of gold predicts the tribute to be exacted by the Macedonians from a conquered people. In this way, Alexander outdoes his Persian opponent by capping Darius' explanation of the symbolic message with a new and stronger interpretation of his own. The same artefacts that were for Darius tokens of feebleness and childishness, these same things become in Alexander's mouth the heralds of manly and warlike prowess. The two solutions, as a whole, construct an ascending scale from loss to gain, from underling to overlord, from weakness to force and dominance ${ }^{37}$.

This climactic pattern is peculiar and unique in the narrative of the Alexander Romance. No such effect can be traced in the Scythian legend of Herodotus and Pherecydes. In this latter story, the various items dispatched by the Scythians have practically the same signification in both solutions: the mouse stands for the earth, the frog for water, the bird for the air or heaven ${ }^{38}$, the arrow for the Scythians' weapons, and the plough (solely in Pherecydes' variant) for the entire Scythian land. The two contrasted explanations are produced only because each solver combines the objects and their symbolic values in a different manner. There is no kind of gradation between the allegorical meanings; the items themselves do not stand for something feebler or stronger in the first solution by comparison to the second one. The placement of the two differing interpretations in an ascending scale is a new and original trait added in Pseudo-Callisthenes' story and totally unparalleled in the Scythian legend. There is nothing in Herodotus' or Pherecydes' text that could have inspired this effect.

${ }^{36}$ On this point, cf. Konstantakos (2015: 142-147).

${ }^{37}$ For further analysis of this pattern of escalation, see Konstantakos (2015: 142-148); cf. Konstantakos (2008: 76); Konstantakos (2010).

${ }^{38}$ There is an isolated exception to this general scheme, traceable only in Herodotus' text, where the meaning of the bird is substantially changed between Darius' and Gobryas' interpretations. The Persian king oddly takes the bird to mean the Scythians' horses - possibly a sign of his perplexity and mystification in front of the visual conundrum. More naturally, Gobryas associates the bird with the air and flying. Anyhow, even with this semantic alteration, there is no sense of gradation or scale between the former and the latter solution. Horses and flight in the air, when taken as a sequence, do not entail any kind of movement or progress from weaker to stronger; they are simply different notions, respectively accommodated to the pro-Persian and the anti-Persian interpretation of the ambiguous items. In Pherecydes' version, on the other hand, both solutions attribute the same symbolism to the bird — air or flying up — without essential variance. For further discussion of this discrepancy, see West (1988: 210-211); Schubert (2010: 93-101); and Konstantakos $(2015: 139,143)$ with further references. 
It would thus be inaccurate to claim that the contest of Alexander and Darius is based solely on the ambiguity of symbols and can therefore be explained wholly and exclusively as a derivative of the Herodotean precedent. On the contrary, the peculiar scale structure indicates that the Scythian legend cannot have been the only source of inspiration for the episode of Pseudo-Callisthenes. Clearly, another narrative model is also operating within the tale about Alexander, merging and interacting with the elements borrowed from the Herodotean or Pherecydean story-pattern. It is this second model that must have inspired the new and original motifs of Alexander's adventure, especially the gradation of the different interpretations from weaker to stronger.

At this point, another possible misunderstanding should be clarified. The climactic structure or escalation effect, as detected above in the episode of the Alexander Romance, must not be confused with the well-known rhetorical figure which is usually called "climax", "incrementum", "gradation", or "crescendo". By definition, this figure of rhetoric consists of a sequence of terms placed in ascending order of intensity. The enumerated words or phrases become progressively stronger and thus gradually intensify the description of an object or situation, creating a kind of build-up. This series of increasing terms is included within the discourse of a single speaker, who uses the rhetorical crescendo in order to stress a particular point. The effect of this rhetorical figure is produced by purely linguistic means; the close juxtaposition and accumulation of words or phrases, which describe a certain notion or quality with augmenting force and emphasis, brings about the sense of build-up ${ }^{39}$.

Turning to the story of Pseudo-Callisthenes, it is evident that the peculiar use of the escalation effect in this text is very different from the rhetorical model described above, with regard to a number of important features. In the narrative of the Alexander Romance (1.36-38), there is no enumeration or accumulation of progressively stronger terms or phrases within the speech (or the writing) of a single personage. The structure of the scale is produced by the explanations successively given by different characters for the same set of symbolic items. There is no individual orator who arranges the membra of his discourse in such a way as to produce a gradual increase in degree or emphasis. Rather, it is the flow of the narrative itself that brings together into a sequence the interpretative statements which create a pattern of climactic augmentation. Further, the sense of increase and climax in Alexander's adventure is not really a matter of words or phrases and their rhetorical placement in the text. The gradation is rather produced by the objects themselves and the ideas which the two adversaries adduce in turn as notional equivalents of the symbolic objects. Pseudo-Callisthenes' account offers a "crescendo" of concepts, not of rhetorical membra; and its "scale of interpretations" is developed in the course of a narrative arc, by means of the actions and pronouncements of contesting characters, not as a result of specially ordered segments of speech.

${ }^{39}$ See especially Kirby - Poster (1998) and Lausberg (1998: 118, 190-193, 213-214, 278-280, 293 295, 299-302, 410) with detailed definitions and many examples; see also Lanham (1991: 10, 26-28, 36); Bauer (1992: 447); Celentano (1992: 38-39, 700-701); Matuschek (1992); Klinkert (1996); Valenti (1998); Dean Anderson (2000: 29, 57-58). 
There is nothing in the ordinary rhetorical handbooks that might cover with exactitude this kind of notional climax and storytelling crescendo. Naturally, there may be some influence from the devices of rhetoric on the story of the two enemy kings. The Briefroman or collection of fictitious letters, as a genre, evolved under the auspices of the rhetorical schools; and the epistles inserted into the Alexander Romance preserve some of the distinctive oratorical flavour of ancient scholastic exercises ${ }^{40}$. However, the primarily narrative nature and function of Pseudo-Callisthenes' scale effect is fundamentally different from the rhetorical use of the crescendo. This factor calls us to consider whether there may have been also a purely narrative exemplar for the climactic structure of the competition between Alexander and Darius.

At this juncture, the tales about contests of magical creations, such as those examined above (section 1), may be considered as a possible source of inspiration. The narratives of this type - especially the Egyptian and Near-Eastern examples - are based precisely on a pattern of escalation and climactic progress, which presents strong analogies to the structure of the contest of the two monarchs in Pseudo-Callisthenes. In every agon of magical transformation, the winning contestant succeeds in producing creatures mightier than those of his opponent. When the evil Urğirnuna creates a ewe, a cow, or a gazelle, the witch Sağburu brings forth respectively a wolf, a lion, and a tiger, which rip apart and devour her enemy's tamer animals. When the Kushite sorcerer makes a large fire break out, Horus of Paneshy causes a heavy rainstorm, which extinguishes the flames; and so forth. A comparable process can be observed in the confrontation of the Macedonian and the Persian king. In Alexander's discourse the symbolic objects prove "mightier" - i.e. standing for more powerful concepts — than they were in Darius' writing. Both in the magical fairytales and in the Hellenistic romance, the effect of the scale operates on the level of objects and ideas. It is caused by the very things or creatures that are used in the competition, and by their comparative powers and qualities; it is not produced simply by the rhetorical arrangement of terms or phrases.

Most importantly, in both cases the climactic pattern is integrated into a narrative context; it emerges from the flow of the narrative itself and from the interaction of the characters. It is significant, in this respect, that the magical tales and the episode of the Alexander Romance belong to the same essential type of narrative, the "wisdom contest"; they all revolve around a confrontation and competition in a special kind of intelligence and knowledge. In the fairytales of metamorphoses, the two extraordinarily talented opponents carry out an agon in magic power, i.e. in the capacity for the manipulation of reality through spiritual operations. Similarly, the story of Alexander and Darius focuses on another spiritual contest between two highly competent adversaries, a contest which concerns a different but kindred type of wisdom, namely, the manipulation of language and ideas. It is viable, therefore, to consider the folktales of magical transformation as a possible source of influence on the shaping of PseudoCallisthenes' episode. Such tales may have provided the gradational structure of the agon as a narrative pattern in a contest story — an important ingredient in Alexander's

${ }^{40}$ See Merkelbach (1977: 48-55); Stramaglia (1996: 106-113); Rosenmeyer (2001: 174-192); Jouanno (2002: 19-21); Stoneman (2007: xxvi-xxvii, xliv-xlv). 
adventure, which is neither traceable in the Herodotean model nor comparable to the rhetorical figures of crescendo.

There is, of course, a crucial difference between the episode of Pseudo-Callisthenes and the magical Märchen: the former does not entail any element of magic. The Macedonian and the Persian king are not using sorcery; nor do they create the actual objects by employing witchcraft. They only produce constructs of words, the allegorical explanations of already extant artefacts. Nevertheless, this discrepancy can be explained as a result of the assimilation of the fairytale model to the generic requirements of a historical legend - that is, a fictitious narrative concerning historical personages (such as the kings Alexander and Darius) and set in a recognizable and lifelike milieu of the recent past ${ }^{41}$.

More specifically, in the narrative of Pseudo-Callisthenes the two adversaries may be said to "metamorphose" the given items - only this time the metamorphosis is carried out in a figurative sense, by means of the two kings' contrasted discourses. The gifts per se, as material beings, are only neutral stuff, without inherent meaning. The two contestants furnish these neutral pieces with special meaning through the symbolic interpretation that each one of them makes up by use of language. In this respect, Alexander and Darius are indeed engaging in an escalating "transformation combat"; they transform the common objects into different entities by rendering them into symbols of one or the other idea. The conflicting rulers make the objects what they are; they bring the items into being, not materially but conceptually. They give notional shape to the material things, casting them into different mental forms.

It is noteworthy that Alexander and Darius perform this function on the same series of objects: the whip, ball, and coffer, which are sent as gifts to the young Macedonian. Each one of the two opponents takes the same material entities and metamorphoses them into different concepts, with a view to competing against his enemy. This process recalls, to some extent, the magical contest of the Sumerian epic. In the Sumerian narrative as well, the two sorcerers use identical, undifferentiated stuff in order to create their diverse animals; in every stage of the combat, both rivals throw into the river the same thing (fish spawn or a copper artefact, according to the proposed interpretations) and then take out of the water their different creatures. Apparently, it is this neutral, always constant item which serves as the primary material for the magical fabrication of the various products. The witch and the wizard of the Sumerian myth execute in the material world what Alexander and Darius effect on the level of words. In both cases, the same object or group of objects serves as the basis for the generation of contrasted transformations. A similar pattern is repeated in the Biblical episode of the Exodus: identical artefacts (the rods of Aaron and the Egyptian magicians) are used as raw stuff for the magical creation of differently empowered beasts (weaker and stronger serpents).

The story of Alexander and Darius, therefore, transfers to a secondary but realistically credible level of metaphor what the tales of magical transformation contests present as literal but fairy-like reality. The competition between the Persian and

${ }^{41}$ On the narrative genre of the historical legend and its main features, see Bascom (1965); Hansen (2002: 2, 13-16, 25-26); Röhrich - Uther - Brednich (2004). 
the Macedonian ruler can be read as a conscious and artful literary reworking of the Märchen about wizardry combats. In Pseudo-Callisthenes' narrative, the fairytale pattern is rationalized and adapted to the conditions of lifelikeness and verisimilitude, in accordance with the generic conventions of the historical legend, which the author of the Hellenistic epistolary novel about Alexander's campaigns felt obliged to keep. Obviously, an account - however fictionalized and novelistic - about Alexander's fairly recent wars against the Achaemenid Empire could not accommodate exploits of magic and supernatural transformations of objects. Thus, the fantastic elements had to be themselves transformed into something more acceptable to the heroic but wholly humanized and rational milieu of such historical adventures.

In this connection, it is not fortuitous that Alexander and Darius use language as the means of metamorphosing the common objects into competing notions. In some of the narratives of magical combat, both ancient and later ones, the conflicting sorcerers similarly exploit words as the medium for exercising their wondrous powers and bringing about the magical creation. In the Egyptian novella of Setne, the two wizards either write down or orally recite spells (i.e. strings of words) in order to produce the creatures they desire. The Kushite composes a written magic formula to conjure up the great fire, the dense mist, and the huge stone vault; Horus of Paneshy similarly brings about rain with a written spell, and recites other formulaic incantations to dispel the cloud, produce the papyrus boat and the fowlers with their knives ${ }^{42}$. The contest between Lemminkäinen and the Master of Northland in the Kalevala follows the same process. The two heroes "sing forth" their various creatures (pool of water, bull, wolf, hare, dog, squirrel, marten, fox, hen, and hawk); they produce them by chanting miraculous songs, as though turning the musically intoned words and lyrics into threedimensional entities.

Something of this magical power of speech survives in the rationalized form of the story about Alexander. The latter and his Persian opponent are also masterful manipulators of words. They employ discourse and scripts to effect the transformation of plain things into symbolic entities, to turn matter into ideas. Indeed, they exchange written texts (viz. letters) for this purpose, much like the sorcerers in the Egyptian novella, who counter each other by writing down spells.

There are also other analogies between the magical Märchen and the narrative found in Pseudo-Callisthenes, with regard to various circumstantial details. In the ancient eastern examples of the tale-type, the transformation combat is inscribed within a broader context of political conflict between enemy states or peoples. In the Sumerian poem, the two opposed sorcerers act as champions of the conflicting cities and their respective kings. Urğirnuna is an agent of the ambitious Ensuhgirana of Aratta, who wishes to subjugate Unug to his rule; Sağburu, on the other hand, comes to help the land of Unug resist the devastating attack of black magic launched by the Arattan enemy. The issue at stake in the wizardry contest comprises much more than the personal prestige of the contesting shamans. In fact, the trophy is the primacy of political power and the domination of one kingdom over the other; if the wizard from Aratta wins, the lord of this latter city will ensure the submission of Enmerkar and Unug. By contrast,

${ }^{42}$ See on this point Ritner (1993: 70-71) and Simpson (2003: 486). 
the victory of Sağburu, the protector of Sumer, immediately obliges the Master of Aratta to acknowledge Enmerkar's superior authority.

The situation is similar in the Egyptian novella of Setne. The wizard from Nubia serves as the agent and champion of the chieftain of Kush; it is this latter ruler who has ordered his magician to use his miraculous capacities for harming the pharaoh of Egypt, the greatest enemy of the Kushite kingdom. Before meeting with his Egyptian opponent in the contest, the Nubian performs indeed a magical feat which is deeply humiliating for the pharaoh: the latter is marvellously transferred to Kush, where he receives 500 blows of the whip. Not surprisingly, most of the Nubian's artifices in the subsequent magical combat aim again at injuring the Egyptian monarch and his council, whether physically or politically. The fire threatens to burn down the entire Egyptian court; the dense mist and the stone vault intend to make the pharaoh and his noblemen invisible and cut them off from their country. Horus of Paneshy, the Egyptian priest, counters the Nubian's tricks precisely in order to protect his own king and by extension preserve the honour of Egypt in face of the enemy. Finally, the Biblical story of the Exodus also brings into confrontation the chiefs of two opposed nations. Aaron and Moses are the leaders of the Hebrew people who are seeking freedom. The Egyptian sorcerers deputize for their pharaoh, the despot who wishes to maintain his authority over the subject Hebrew population. The ultimate prize in the contest of magic is once again the sovereignty or the subjugation of an entire political entity.

Alexander and Darius are involved in a comparable conflict of states. The exchange of letters concerning Darius' gifts occurs shortly after the Macedonian king has begun his Asiatic campaigns, exactly when he is initiating his great war against the powerful Achaemenid Empire. Alexander has just subdued Tyre and annexed the whole territory of Syria; he is preparing to march further into inland Asia and continue his conquests. Open military clash with the Persian army will soon follow in the narrative of the Alexander Romance. The battle at Issos is described a few chapters afterwards (1.41) and it is surrounded by other epistles exchanged between Darius, Alexander, and their commanders (1.40 and 42). Pseudo-Callisthenes and the epistolary collections in the papyri also contain further missives which refer to this same battle and its aftermath ${ }^{43}$. Clearly, the events at Issos occupied a prominent place in the epistolary novel. The contest of wit around the symbolic presents functions in the novelistic plot as a prelude and preparation for the immediately following armed combat on the battlefield ${ }^{44}$. Overall, the stakes of the confrontation between Alexander and Darius are tied up with the issues of international power and imperialist dominion, exactly as

${ }^{43}$ See Merkelbach (1977: 234-240) for the collected texts; see also Giuliano (2010: 210-218) for discussion and analysis.

${ }^{44}$ Similarly in the Kalevala, the magical transformation contest is directly followed by an armed duel of the two opponents, who fight each other with swords, until one of them is killed. The same sequence occurs in a tale of Somadeva's Kathassaritsāgara, in which the Indian Emperor confronts an enemy king; see Penzer - Tawney (1924-1928: VIII, 79-80). An analogous narrative pattern is traceable in the Exodus; the contest of magical transformations (7.8-12) and the other marvellous feats that Moses performs in competition with the Egyptian sages (7.15-8.15) are followed by full military persecution of the fugitive Hebrew population by the pharaoh's army (14.6-10 and 14.23-30). This time, however, the Israelites do not need to give battle, since the Lord protects them with the miracle of dividing the waters. 
in the Near-Eastern magical narratives examined above. The winner will subjugate his opponent's empire and rule over his opponent's lands and peoples. This is the trophy acquired by Alexander in the end.

Further analogies between these ancient stories can be detected on the level of character portrayal. In the Sumerian poem, the ruler of Aratta, the patron of the losing magician and enemy of the glorified Sumerian king Enmerkar, is depicted as an arrogant and overbearing despot. He unjustifiably boasts of being the goddess Inanna's favourite lover and haughtily demands that Enmerkar submit to his authority. When Enmerkar proudly refuses, the lord of Aratta is too conceited to admit defeat and resorts to a practitioner of black magic in order to harm the enemy land ${ }^{45}$. This leads to the lord's final undoing, since his champion wizard is vanquished in the contest against Sağburu. In the Egyptian novella, similar presumptuousness characterizes not only the chieftain of Kush but also his agent, the Nubian sorcerer. The chieftain looks out for a chance to shame the magnificent pharaoh of Egypt, out of spite for the pharaoh's glory. As for the Nubian sorcerer, he repeatedly displays boastfulness. At first, he brags of being able to humiliate the great pharaoh with his magical tricks. Upon meeting with Horus of Paneshy, he haughtily claims that he himself has taught his opponent the secrets of witchcraft. Even when he reappears after 1500 years in the form of a Kushite stranger, he maintains his swaggering attitude; he impudently confronts the Egyptian king and his noble council with an outrageous problem and declares himself ready to proclaim the humiliation of Egypt ${ }^{46}$. Again, it is this kind of arrogance that brings about the Nubian's end, because Horus/Si-Osire proves a better wizard and defeats the Nubian on both occasions. The pharaoh and his magicians in the Exodus are equally distinguished by conceited stubbornness and overestimation of their own powers, as shown by many passages of the book ${ }^{47}$.

In the epistles incorporated into the Alexander Romance, Darius, the losing antagonist, demonstrates the same arrogant and hubristic character. He overrates his own forces and military prowess; he heaps up extremely pompous titles for his royal person and even presents himself as a god, a kinsman and companion of divinities. He also despises and scorns Alexander, repeatedly brands him as a small child or a lawless brigand, and underestimates the threat posed by the Macedonian army ${ }^{48}$. It is due to this kind of alazoneia that Darius initiates the contest of wit around the symbolic objects; he sends Alexander the gifts in order to disparage him as a playing minor, and plainly underrates his opponent's mental capacity of reinterpreting these items. Darius' arrogance, therefore, is responsible both for his involvement in the intellectual

\footnotetext{
${ }^{45}$ Verses 22-169; see Berlin (1979: 38-51); Vanstiphout (2003: 28-39); Black - Cunningham - Robson - Zólyomi (2004: 4-8).

${ }^{46}$ See Griffith (1900: 162-163, 174-179, 196-197); Brunner-Traut (1965: 198-199, 202-204, 210); Lichtheim (1980: 142, 144-145, 149); Maspero (2002: 125, 128-129, 134); Simpson (2003: 477, 480481, 486); Bresciani (2007: 898, 901-902, 906).

${ }^{47}$ See Exodus 5.2-9, 7.13, 7.22-23, 8.11, 8.15, 9.7, 9.12, 9.34-35, 10.10-11, 10.20, 10.27-28, 14.5-30.

${ }^{48}$ For the portrayal of Darius in the epistolary collection, see van Thiel (1974: xxii-xxiii); Merkelbach (1977: 48-51); Franco (1999: 83); Rosenmeyer (2001: 177-180, 182); Jouanno (2002: 193-194); Giuliano (2010: 211-215, 220); Jouanno (2012: 106-109); Whitmarsh (2013: 177-181). All of them adduce several textual examples.
} 
competition and for his defeat in it; the same thing happens with the evil and conceited magicians or rulers in the Sumerian, Egyptian, and Hebrew stories.

Alexander, on the other hand, both in the overall storyline of the Alexander Romance and more particularly in the letter collection, is portrayed as a very clever personage: an expert manipulator of language and artifices, an excellent solver of riddles and other intellectual problems, and even a cunning trickster ${ }^{49}$. This is how he manages to win his "battle of wits" against Darius and cap him with a stronger interpretation of the visual conundrum. In this respect, the young Macedonian king resembles the victorious magician of the transformation stories, especially of the Sumerian and Egyptian narratives. The witch Sağburu and Horus of Paneshy are equally cunning characters, endowed with spiritual alertness and capacity for clever tricks. The same holds true for the heroes of many folktales about magical contests of metamorphoses. Especially in the multitudinous examples of tale-type ATU 325 ("The magician and his pupil"), the young protagonist and eventual winner of the transformation combat is depicted from the beginning as a consummate trickster ${ }^{50}$.

There is a final question to be asked: how could the author of the Hellenistic Briefroman about Alexander's campaigns have become familiar with tales of transformation contests? As noted above (section 1), the extant traces of magical combats in ancient Hellenic mythology conform to the standard story-pattern of self-transformation, in which the competitors metamorphose themselves into various creatures. There is no known Greek version of a proper contest in magical fabrication of conflicting beings, comparable to the confrontations described in the Sumerian epic, the Egyptian novella of Setne, or the Exodus. Nonetheless, this latter variant clearly enjoyed a wide dissemination in the ancient world; it is attested over a large area (Mesopotamia, Canaan, Egypt) and through an extensive period of time (from the late 3rd millennium B.C. to the Roman age). It might thus have easily passed into the Greek tradition as well, at least as an oral tale. Popular narrative lore, in the form of myths, legends, or folktales, was exchanged between the Greek-speaking world and the Near East from early on. Contacts naturally multiplied and intensified in the Hellenistic era, after Alexander's conquests in Egypt and Asia. It was during this epoch of vivid interaction between Greek and eastern cultures that the legends about the Macedonian conqueror were formed and the Briefroman that recounted his expedition was composed. Therefore, the author of this latter epistolary work could easily have known some tale or tales about a magical combat of competing creations. Such a tale will have influenced the narrative of the intellectual agon between Alexander and Darius.

In this connection, it is especially noteworthy that the same kind of wizards' competition occurs in an Egyptian novella from the cycle of Setne Khaemwaset, which

${ }^{49}$ See Stoneman (1995); Konstan (1998); Rosenmeyer (2001: 172-180, 192); Jouanno (2002: 200208, 230-232, 259-260, 286-287, 356-359, 413-414); Stoneman (2007: xli-xlii, lxxi-lxxiii); Stoneman (2008: 108-111); Jouanno (2009: 41-47); Anderson (2012: 95-97).

${ }^{50}$ During his apprenticeship at the sorcerer's house, the young hero learns stealthily and by deceit the secrets of his master's magical craft. Subsequently, he cheats the sorcerer in order to be released from service. He proceeds to use the wondrous spells he has learned, so as to defraud other people at the market and gain money. See the bibliography above (notes 1 and 2) for many specimens of this tale-type from all around the world. 
appears to have been formed by the early Ptolemaic age. The Alexander Romance, as a whole, is generally viewed as a product of the Graeco-Egyptian environment, composed in Alexandria and incorporating many Ptolemaic and Egyptian elements ${ }^{51}$. These include an extensive story arc concerning the adventures of Nectanebo, the pharaoh-magician, who supposedly had a secret affair with Olympias and begot Alexander (1.1-12). This narrative doubtless derives from Egyptian legends about Nectanebo, possibly even from a written Demotic Egyptian novella or novelistic cycle concerning this legendary pharaoh. In Pseudo-Callisthenes, Nectanebo is depicted as an expert sorcerer; his feats of wizardry strongly recall the favourite Egyptian genre of fantastic stories about magicians, such as are found e.g. in the Papyrus Westcar or the cycle of Setne ${ }^{52}$.

It is of course difficult to determine with exactitude the local origins and milieu of the author of the Hellenistic "epistolary novel", which was used as a source of the Alexander Romance. If the creator of this Briefroman also lived and worked in Alexandria ${ }^{53}$, he could have been familiar with fantastic tales of Egyptian origin, either via Greek translations or through the diffusion of Egyptian lore into the oral tradition of the Ptolemaic territories. Such tales doubtless included magical contests, like the one between Horus of Paneshy and his Nubian opponent in the Setne narrative ${ }^{54}$.

\section{BIBLIOGRAPHY}

AlsTER, Bendt (1973), «An Aspect of "Enmerkar and the Lord of Aratta"», Revue d'Assyriologie et d'Archéologie Orientale 67: 101-109.

- (1995), «Epic Tales from Ancient Sumer: Enmerkar, Lugalbanda, and Other Cunning Heroes», in J. M. Sasson (ed.), Civilizations of the Ancient Near East, New York: 2315-2326.

Anderson, Graham (2000), Fairytale in the Ancient World. London-New York.

- (2012), «The Alexander Romance and the Pattern of Hero-Legend», in R. Stoneman K. Erickson - I. Netton (eds.), The Alexander Romance in Persia and the East, Groningen: 81-102.

${ }^{51}$ See Stoneman (1991: 10-12, 14-17); Fraser (1996: 211-221); Jouanno (2002: 57-125); Stoneman (2007: xxviii-xxx, xlvii-1, liii-lvi, lxiv-lxv).

${ }^{52}$ See Braun (1938: 19-25, 38-43); Perry (1966); Jasnow (1997); Aufrère (2000); Jouanno (2002: 57-65, 83-88, 93-94, 118-123); Konstantakos (2009); Matthey (2011).

${ }^{53}$ This hypothesis is advanced by Stoneman (2007: liv). Already Merkelbach (1977: 52-53) noted that one of the epistles (addressed by Alexander to the Persian people after Darius' death, Ps.-Callisth. 2.21.3-21) includes numerous parallels to the phraseology and the themes of Ptolemaic royal proclamations. One or more collections of such fictional letters were clearly circulating in Ptolemaic and Imperial Egypt, as attested by the papyri.

${ }^{54}$ I am grateful to the editor-in-chief of the Cuadernos de Filología Clásica: Estudios griegos e indoeuropeos, Professor Ignacio Rodríguez Alfageme, and to the anonymous referees of the journal for their valuable comments, which helped me sharpen and refine my discussion, especially in the second part of the article. Responsibility for errors and controversial statements remains, of course, entirely mine. I also heartily thank my friends and colleagues, Professor William Hansen, Dr. Michael Kardamitsis, and Dr. Agis Marinis, for very useful bibliographical aid and suggestions. 
Aufrère, Sydney H. (2000), «Quelques aspects du dernier Nectanébo et les échos de la magie égyptienne dans Le Roman d'Alexandre», in A. Moreau - J.-C. Turpin (eds.), La magie. Actes du colloque international de Montpellier 25-27 Mars 1999, I, Montpellier: 95-118.

BAKola, Emmanuela (2010), Cratinus and the Art of Comedy. Oxford.

BAsCOM, William (1965), «The Forms of Folklore: Prose Narratives», The Journal of American Folklore 78: 3-20.

BAUER, Barbara (1992), «Amplificatio», Historisches Wörterbuch der Rhetorik 1: 445-471.

Berlin, Adele (1979), Enmerkar and Ensuhkešdanna: A Sumerian Narrative Poem. Philadelphia.

Bernabé, Alberto (1996), Poetarum Epicorum Graecorum Testimonia et Fragmenta, I. Stutgardiae-Lipsiae.

Black, Jeremy (1998), Reading Sumerian Poetry. Ithaca, NY.

Black, Jeremy - Cunningham, Graham - Robson, Eleanor - Zólyomi, Gábor (2004), The Literature of Ancient Sumer. Oxford.

Bolte, Johannes - Polívka, Georg (1913-1932), Anmerkungen zu den Kinder- und Hausmärchen der Brüder Grimm, I-V. Leipzig.

Bosley, Keith (1999), The Kalevala: An Epic Poem after Oral Tradition by Elias Lönnrot. Oxford.

Bounoure, Gilles - Serret, Blandine (1992), Pseudo-Callisthène: Le Roman d'Alexandre. La vie et les hauts faits d'Alexandre de Macédoine. Paris.

Braun, Martin (1938), History and Romance in Graeco-Oriental Literature. Oxford.

BresCiAni, Edda (1975), «Chaemwese-Erzählungen», Lexikon der Ägyptologie 1: 899-901.

- $\left(2007^{4}\right)$, Letteratura e poesia dell'antico Egitto. Cultura e società attraverso i testi. Torino. BrunNER-Traut, Emma (1965²), Altägyptische Märchen. Düsseldorf-Köln.

Buxton, Richard (2009), Forms of Astonishment: Greek Myths of Metamorphosis. OxfordNew York.

CAllu, Jean-Pierre (2010), Julius Valère: Roman d'Alexandre. Turnhout.

Campbell, John Francis (1860), Popular Tales of the West Highlands Orally Collected with a Translation, II. Edinburgh.

Cavallo, Guglielmo - Maehler, Herwig (2008), Hellenistic Bookhands. Berlin-New York.

Celentano, Maria S. (1992), «Accumulatio» and «Antiklimax», Historisches Wörterbuch der Rhetorik 1: 36-39, 700-701.

Chauvin, Victor (1892-1922), Bibliographie des ouvrages arabes ou relatifs aux Arabes publiés dans l'Europe chrétienne de 1810 à 1885, I-XII. Liège-Leipzig.

CHILD, Francis James (1904), English and Scottish Popular Ballads. Boston-New York.

Clouston, William A. (2002²), Popular Tales and Fictions: Their Migrations and Transformations, ed. C. Goldberg. Santa Barbara-Denver-Oxford.

Conen, Sol (1973), Enmerkar and the Lord of Aratta. Ph.D. Dissertation, University of Pennsylvania.

Cook, Arthur Bernard (1914), Zeus: A Study in Ancient Religion, I. Cambridge.

Cosquin, Emmanuel (1922), Études folkloriques. Recherches sur les migrations des contes populaires et leur point de départ. Paris.

DAviEs, Malcolm (1988), Epicorum Graecorum Fragmenta. Göttingen.

Dean Anderson, Jr., Roger (2000), Glossary of Greek Rhetorical Terms Connected to Methods of Argumentation, Figures and Tropes from Anaximenes to Quintilian. Leuven. 
De BlÉCourt, Willem (2013), «Zauberer und Schüler», Enzyklopädie des Märchens 14: 1165 1168.

ECKARD, Gilles (1997), «Habenam et pilam loculosque cum aureis. Les présents envoyés par Darius dans le Roman d'Alexandre et les vestiges d'une formule trifonctionnelle en ancien français», in D. Knoepfler (ed.), Nomen latinum. Mélanges de langue, de littérature et de civilisation latines offerts au professeur André Schneider à l'occasion de son départ à la retraite, Neuchâtel-Genève: 247-257.

Forbes Irving, Paul M. C. (1990), Metamorphosis in Greek Myths. Oxford.

Ford, Patrick K. (1977), The Mabinogi and Other Medieval Welsh Tales. Berkeley-Los Angeles-London.

Franco, Carlo (1999), «Il romanzo di Alessandro», QS 49: 45-102.

Fraser, Peter Marshall (1972), Ptolemaic Alexandria, I-II. Oxford.

- (1996), Cities of Alexander the Great. Oxford.

Frazer, James George (1921), Apollodorus: The Library, I-II. Cambridge, MA-London.

Frobenius, Leo (1938), «Das Archiv für Folkloristik», Paideuma 1: 1-19.

Gantz, Timothy (1993), Early Greek Myth: A Guide to Literary and Artistic Sources. Baltimore-London.

Giuliano, Laura (2010), «PSI XII 1285 e le lettere del ciclo di Alessandro», in G. Bastianini A. Casanova (eds.), I papiri del romanzo antico. Atti del convegno internazionale di studi (Firenze, 11-12 giugno 2009), Firenze: 207-222.

Griffith, Francis Llewellyn (1900), Stories of the High Priests of Memphis: The Sethon of Herodotus and the Demotic Tales of Khamuas. Oxford.

Grimal, Nicolas (1994), «Le roi et la sorcière», in C. Berger - G. Clerc - N. Grimal (eds.), Hommages à Jean Leclant, IV, Le Caire: 97-108.

Gual, Carlos García (1977), Pseudo Calístenes: Vida y hazañas de Alejandro de Macedonia. Madrid.

Gunkel, Hermann (1987), The Folktale in the Old Testament, transl. M. D. Rutter. Sheffield.

HaLlo, William W. (1963), «On the Antiquity of Sumerian Literature», JAOS 83:167-176.

Hansen, William (2000), «Foam-Born Aphrodite and the Mythology of Transformation», AJPh 121: 1-19.

- (2002), Ariadne's Thread: A Guide to International Tales Found in Classical Literature. Ithaca-London.

- (2004), Classical Mythology: A Guide to the Mythical World of the Greeks and Romans. Oxford-New York.

Henderson, Jeffrey (2012), «Pursuing Nemesis: Cratinus and Mythological Comedy», in C. W. Marshall - G. Kovacs (eds.), No Laughing Matter: Studies in Athenian Comedy, London: 1-12.

Herter, Hans (1935), «Nemesis», RE 16.2: 2338-2380.

HofFmann, Friedhelm (2000), Ägypten: Kultur und Lebenswelt in griechisch-römischer Zeit. Eine Darstellung nach den demotischen Quellen. Berlin.

HolzBerg, Niklas (1994), «Der griechische Briefroman: Versuch einer Gattungstypologie», in N. Holzberg - S. Merkle (eds.), Der griechische Briefroman: Gattungstypologie und Textanalyse, Tübingen: 1-52.

Jacobsen, Thorkild (1987), The Harps that once ... Sumerian Poetry in Translation. New Haven-London. 
JASNOw, Richard (1997), «The Greek Alexander Romance and Demotic Egyptian Literature», JNES 56: 95-103.

Jouan, François (1966), Euripide et les légendes des Chants Cypriens. Paris.

Jounnno, Corinne (2002), Naissance et métamorphoses du Roman d'Alexandre. Domaine grec. Paris.

- (2009), «Novelistic Lives and Historical Biographies: The Life of Aesop and the Alexander Romance as Fringe Novels», in G. A. Karla (ed.), Fiction on the Fringe: Novelistic Writing in the Post-Classical Age, Leiden-Boston: 33-48.

- (2012), «The Persians in Late Byzantine Alexander Romances: A Portrayal under Turkish Influences», in R. Stoneman - K. Erickson - I. Netton (eds.), The Alexander Romance in Persia and the East, Groningen: 105-115.

KERÉNYI, Karl (1939), «Die Geburt der Helena. Eine mythologische Studie dis manibus Leonis Frobenii», Mnemosyne 3rd ser. 7: 161-179.

Kirby, John T. - Poster, Carol (1998), «Klimax», Historisches Wörterbuch der Rhetorik 4: 1106-1115.

KLeIN, Jacob (1995), «Shulgi of Ur: King of a Neo-Sumerian Empire», in J. M. Sasson (ed.), Civilizations of the Ancient Near East, New York: 843-857.

KLINKERT, Thomas (1996), «Gesetz der wachsenden Glieder», Historisches Wörterbuch der Rhetorik 3: 926-929.

KöHLER, Reinhold (1898), Kleinere Schriften, I. Zur Märchenforschung. Weimar.

Konstan, David (1998), «The Alexander Romance: The Cunning of the Open Text», Lexis 16: 123-138.

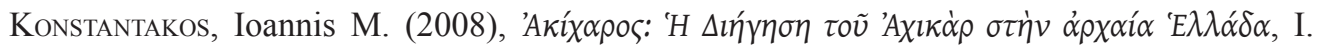

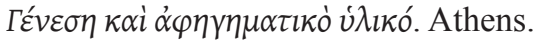

- (2009), «Nektanebo in the Vita Aesopi and in Other Narratives», C\&M 60: 99-144.

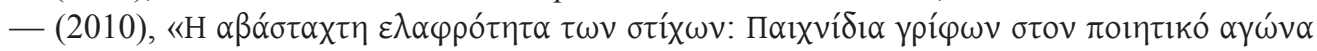

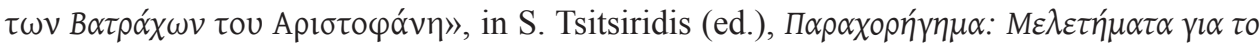

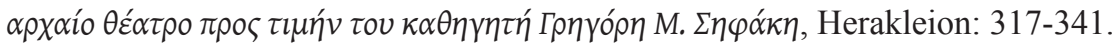

- (2013), «Zeus», Enzyklopädie des Märchens 14: 1327-1332.

- (2015), «Alexander and Darius in a Contest of Wit (“Alexander Romance” 1.36-38): Sources, Formation, and Storytelling Traditions», Acme 68: 129-156.

Kramer, Samuel Noah - JACOBSEN, Thorkild (1954), «Enmerkar and Ensukušsiranna», Orientalia 23: 232-234.

Kroll, Guilelmus (1926), Historia Alexandri Magni (Pseudo-Callisthenes), I. Recensio vetusta. Berlin.

Lanham, Richard A. (1991²), A Handlist of Rhetorical Terms. Berkeley-Los Angeles-London.

Lausberg, Heinrich (1998), Handbook of Literary Rhetoric. A Foundation for Literary Study, transl. M. T. Bliss - A. Jansen - D. E. Orton. Leiden-Boston-Köln.

LeSKy, Albin (1947), Thalatta: Der Weg der Griechen zum Meer. Wien.

Lichtheim, Miriam (1980), Ancient Egyptian Literature: A Book of Readings, III. The Late Period. Berkeley-Los Angeles-London.

Luppe, Wolfgang (1974), «Zeus und Nemesis in den Kyprien — Die Verwandlungssage nach Pseudo-Apollodor und Philodem», Philologus 118: 193-202.

— (1975), «Nochmals zur Nemesis bei Philodem», Philologus 119: 143-144. 
Marzolph, Ulrich - van Leeuwen, Richard (2004), The Arabian Nights Encyclopedia. Santa Barbara-Denver-Oxford.

Maspero, Gaston (2002²), Popular Stories of Ancient Egypt, ed. H. El-Shamy. Santa BarbaraDenver-Oxford.

Matthey, Philippe (2011), «Récits grecs et égyptiens à propos de Nectanébo II: Une réflexion sur l'historiographie égyptienne», in N. Belayche - J.-D. Dubois (eds.), L'oiseau et le poisson. Cohabitations religieuses dans les mondes grec et romain, Paris: 303-328.

MatuscheK, Stefan (1992), «Anadiplose», Historisches Wörterbuch der Rhetorik 1: 471-472.

Merkelbach, Reinhold (1977²), Die Quellen des griechischen Alexanderromans. München.

Michalowski, Piotr (1995), «Sumerian Literature: An Overview», in J. M. Sasson (ed.), Civilizations of the Ancient Near East, New York: 2279-2291.

Ninck, Martin (1921), Die Bedeutung des Wassers im Kult und Leben der Alten. Eine symbolgeschichtliche Untersuchung. Leipzig.

Olivieri, Alexander (1897), Pseudo-Eratosthenis Catasterismi. Lipsiae.

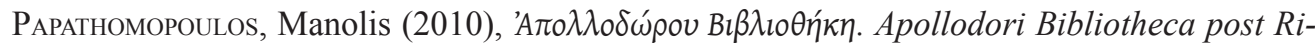

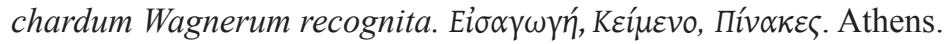

Penzer, Norman Mosley - TAwney, Charles Henry (1924-1928), The Ocean of Story, being C. H. Tawney's Translation of Somadeva's Kathā Sarit Sägara (or Ocean of Streams of Story), Now Edited with Introduction, Fresh Explanatory Notes and Terminal Essay by N. M. Penzer, I-X. London.

Perry, Ben Edwin (1966), «The Egyptian Legend of Nectanebus», TAPhA 97: 327-333.

PiePer, Max (1931), «Zum Setna-Roman», Z̈̈S 67: 71-74.

Ritner, Robert K. (1993), The Mechanics of Ancient Egyptian Magical Practice. Chicago.

RÖHRICH, Lutz - UtHER, Hans-Jörg - BREDNICH, Rolf Wilhelm (2004), «Sage», Enzyklopädie des Märchens 11: 1017-1049.

RöLleKe, Heinz (20076), Brüder Grimm: Kinder-und Hausmärchen. Ausgabe letzter Hand mit den Originalanmerkungen der Brüder Grimm, I-III. Stuttgart.

Rose, Herbert Jennings (1958 $)$, A Handbook of Greek Mythology. London.

Rosenmeyer, Patricia A. (2001), Ancient Epistolary Fictions: The Letter in Greek Literature. Cambridge.

Sauneron, Serge - Yoyotte, Jean (1952), «La campagne nubienne de Psammétique II et sa signification historique», BIAO 50: 157-207.

SCHERF, Walter (1995), Das Märchenlexikon, I-II. München.

Schubert, Charlotte (2010), Anacharsis der Weise: Nomade, Skythe, Grieche. Tübingen.

Schwarzbaum, Haim (1968), Studies in Jewish and World Folklore. Berlin.

SEVERYns, Albert (1928), Le cycle épique dans l'école d'Aristarque. Liège-Paris.

Simpson, William Kelly, ed. (2003 3 ), The Literature of Ancient Egypt: An Anthology of Stories, Instructions, Stelae, Autobiographies, and Poetry. New Haven-London.

Stoneman, Richard (1991), The Greek Alexander Romance. London.

- (1995), «Riddles in Bronze and Stone: Monuments and their Interpretation in the Alexander Romance», Groningen Colloquia on the Novel 6: 159-170.

- (2007), Il Romanzo di Alessandro, I, transl. T. Gargiulo. Milano.

- (2008), Alexander the Great: A Life in Legend. New Haven-London.

Storey, Ian C. (2011), Fragments of Old Comedy, I. Cambridge, MA-London. 
Stramaglia, Antonio (1996), «Fra 'consumo' e 'impegno': usi didattici della narrativa nel mondo antico», in O. Pecere - A. Stramaglia (eds.), La letteratura di consumo nel mondo greco-latino, Cassino: 97-166.

Thompson, Stith (1955-1958), Motif-Index of Folk-Literature, I-VI. Bloomington.

- (1977), The Folktale. Berkeley-Los Angeles-London.

UtHeR, Hans-Jörg (2004), The Types of International Folktales: A Classification and Bibliography Based on the System of Antti Aarne and Stith Thompson, I-III. Helsinki.

VAlEnTI, Rossana (1998), «Incrementum», Historisches Wörterbuch der Rhetorik 4: 322-325.

Vanstiphout, Herman L. J. (1995), «The Matter of Aratta: An Overview», OLP 26: 5-20.

- (2003), Epics of Sumerian Kings: The Matter of Aratta. Atlanta.

van Thiel, Helmut (1974), Leben und Taten Alexanders von Makedonien. Der griechische Alexanderroman nach der Handschrift L. Darmstadt.

West, Martin L. (2003), Greek Epic Fragments from the Seventh to the Fifth Centuries BC. Cambridge, MA-London.

- (2013), The Epic Cycle: A Commentary on the Lost Troy Epics. Oxford.

West, Stephanie (1988), «The Scythian Ultimatum (Herodotus iv 131, 132)», JHS 108: $207-$ 211.

Whitmarsh, Tim (2013), «Addressing Power: Fictional Letters between Alexander and Darius», in O. Hodkinson - P. A. Rosenmeyer - E. Bracke (eds.), Epistolary Narratives in Ancient Greek Literature. Leiden-Boston: 169-186. 